\title{
IMMUNOFLUORESCENT STUDIES OF HUMAN ARTICULAR CARTILAGE*
}

BY

\author{
PETER BARLAND, ROSAMOND JANIS, AND JOHN SANDSON $\dagger$ \\ Departments of Medicine and Pathology, Albert Einstein College of Medicine, New York, N.Y.
}

The matrix of articular cartilage is produced by chondrocytes and is composed of chondromucoprotein (CMP) enmeshed in a network of collagen fibres. Native CMP consists of chains of chondroitin sulphate and keratin sulphate combined with protein to form large complexes. These complexes can be extracted from cartilage by highspeed homogenization in water (Malawista and Schubert, 1958). Ultracentrifugation of CMP from human articular cartilage at $105,000 \mathrm{G}$. yields two proteinpolysaccharide fractions; one sedimentable, PP-H, and one non-sedimentable, PP-L (Gerber, Franklin, and Schubert, 1960). PP-L is the purer of these fractions and in the adult is composed of approximately equal parts of protein, chondroitin sulphate, and keratin sulphate.

Previous histological studies of the distribution of CMP in articular cartilage have depended upon the metachromatic or other anionic staining properties of chondroitin sulphate and keratin sulphate. In normal human articular cartilage there is diffuse metachromatic staining of the matrix with a slight diminution in the intensity of the staining in the most superficial zone adjacent to the joint space. In osteo-arthritis the superficial zone of articular cartilage becomes fibrillated and vacuolated, and exhibits a striking loss of metachromatic staining (Collins, 1949).

In this paper we describe the use of an immunofluorescent technique to study the distribution of CMP in normal and osteo-arthritic articular cartilage. Specific antisera to CMP were prepared in rabbits and an indirect fluorescent antibody technique was used to localize the CMP in sections of cartilage. The immunofluorescent and metachromatic staining patterns of normal cartilage were

* Supported by United States Public Health Service Grant AM-07343 and by a grant from the New York State Chapter of the Arthritis Foundation.

Foundation. f Investigator of the
York (Contract I-157). studied before and after digestion with hydrolytic $\frac{2}{2}$ enzymes, and these patterns were compared with $\hat{\sim}_{\vec{j}}$ those observed in non-digested osteo-arthriticiv cartilage.

\section{Material and Methods}

Antisera.-CMP was isolated from normal human articular cartilage, normal bovine hyaline cartilage, and $\widehat{O}$ normal porcine hyaline cartilage by the method of Malawista and Schubert (1958).* Rabbits were immunized with $2.5 \mathrm{mg}$. CMP or PP-L from each species. mixed with Freund's complete adjuvant. Booster injections of $1 \mathrm{mg}$. proteinpolysaccharide were given every 4 weeks. Agar double-diffusion studies were performed as described by Ouchterlony (1958). Tanned sheep red blood cell agglutination tests were done by the method $\frac{}{\Phi}$ of Boyden (1951). $1.5 \mathrm{ml}$. (10 mg./ml.) proteinpoly- $\unrhd$ saccharide was used to coat $10 \mathrm{ml}$. of a 3 per cent. $\overrightarrow{\vec{O}}$ suspension of red cells. Absorption was carried out 3 by adding $1 \mathrm{ml}$. lyophilized serum to $1 \mathrm{ml}$. antiserum. The mixtures were incubated at $37^{\circ} \mathrm{C}$. for $1 \mathrm{hr}$ and then at $4^{\circ} \mathrm{C}$. for $16 \mathrm{hrs}$, and the precipitate was removed by centrifugation.

Zone electrophoresis of hyaluronidase-digested human PP-L was performed on blocks of polyvinylchloride 3 (Sandson and Hamerman, 1962) at pH 7.4 (0.04 Mphosphate) at 15 volts $/ \mathrm{cm}$. for $6 \mathrm{hrs}$. Each segment 약 was analysed for hexuronic acid (Dische, 1947), protein (Lowry, Rosebrough, Farr, and Randall, 1951), and $\mathrm{O}$ ability to inhibit the agglutination of sheep cells coated $\supset$ with PP-L by anti-human PP-L.

Histological Specimens.-Samples of human articular $\widetilde{N}$ cartilage were obtained from knee joints of amputated $N$ extremities or immediately post mortem. The degree of $\mathrm{N}$ osteo-arthritis was determined by the gross appearance $\omega$ of the articular cartilage. Slight yellowing, softening,

* These products were generously provided by L. C. Rosenberg, Albert Einstein College of Medicine, and M. Schubert, New York University.

† Geon 427 obtained from B. F. Goodrich, Cleveland, Ohio. 
and roughening were considered early osteo-arthritic changes, while marked roughening and friability indicated advanced osteo-arthritis.

The specimens were divided into thin slices $1.0 \mathrm{~cm}$. long and then either fixed in formal-calcium (Baker, 1946) for $16 \mathrm{hrs}$ at $4^{\circ} \mathrm{C}$., quick-frozen at $-60^{\circ} \mathrm{C}$., and stored at $-20^{\circ} \mathrm{C}$.; or they were immediately quickfrozen and stored. Frozen sections 4-6 $\mu$. in thickness were prepared in an International Cryostat and mounted on coverslips. The immunofluorescent staining patterns obtained with fixed and unfixed tissues were identical. In order to demonstrate changes after enzymatic digestion, unfixed tissue sections were first incubated with the enzyme and then fixed in 10 per cent. buffered formalin in $4^{\circ} \mathrm{C}$. for $2 \mathrm{~min}$.

Immunofluorescent Staining.-Sections were first layered with rabbit antiserum for $30 \mathrm{~min}$. at $37^{\circ} \mathrm{C}$. in a moist chamber. The following antisera to proteinpolysaccharide were employed:

(1) Anti-human CMP absorbed with human serum;

(2) Anti-human CMP absorbed with human CMP;

(3) Anti-bovine CMP;

(4) Anti-porcine CMP.

The sections were washed twice for $10 \mathrm{~min}$. with buffered saline $(p H 7 \cdot 2)$ and then layered for $20 \mathrm{~min}$. at $37^{\circ} \mathrm{C}$. with anti-rabbit gamma globulin goat serum conjugated with fluorescein isothiocyanate.* The sections were then thoroughly washed with buffered saline, mounted on glass slides in glycerol, and observed immediately with a Zeiss fluorescence microscope illuminated by an Osram HB 200 mercury vapour lamp. Optimal fluorescence was obtained with UG $2+$ BG 12 exciter filters, a dark-field condenser, and 41/65 barrier filters. In all experiments parallel control sections were incubated with:

Normal rabbit serum;

Rabbit antiserum specific for human ceruloplasmin; or

Rabbit anti-human CMP absorbed with human CMP; followed by the fluorescein-labelled goat serum as above.

Additional Stains for CMP.-Parallel sections were also stained with either 0.1 per cent. toluidine blue in 30 per cent. ethanol or 0.1 per cent. acridine orange for 5 min. to study metachromasia and cationic affinity, respectively.

\section{Enzymatic Digestion}

(1) Hyaluronidase.-Digestion was performed by layering unfixed sections of cartilage with freshly prepared testicular hyaluronidase $\dagger(750$ turbidity units $/ \mathrm{ml}$., $0.075 \mathrm{M}$ acetate, $p \mathrm{H} 4.7$ ) for 60 and $120 \mathrm{~min}$. at $37^{\circ} \mathrm{C}$. Control sections were incubated with buffer alone.

(2) Papain.-Digestion was accomplished by using freshly-prepared papain $\ddagger$ ( $5 \mathrm{mg} . / \mathrm{ml}$.) in buffer $(0.2 \mathrm{M}$

\footnotetext{
* Antibodies Inc., Davis, California.

+ Wyeth Laboratories, Inc., Philadelphia, Pa.

‡ Worthington Biochemical Corporation, Freehold, New Jersey.
}

phosphate, $p \mathrm{H} 6.3$ ) containing $0.03 \mathrm{M}$ cysteine for 10 and $60 \mathrm{~min}$. at $37^{\circ} \mathrm{C}$. Control sections were incubated with only the buffer containing cysteine.

(3) Lysosomal Enzymes.-Digestion was performed by incubating sections of unfixed articular cartilage with solubilized lysosomal enzymes in buffer $(0 \cdot 1 \mathrm{M} \mathrm{Ac}$, $p \mathrm{H} \mathrm{4.5)}$ for $60 \mathrm{~min}$. at $37^{\circ} \mathrm{C}$. These preparations were obtained by freeze-thaw rupture ( 5 times) of lysosomes* that had been isolated from rat liver, human white blood cells, and rheumatoid synovial membrane by homogenization and density gradient ultracentrifugation (de Duve, Pressman, Gianetto, Wattiaux, and Appelmans, 1955). Control sections were treated with whole lysosomal fractions or with solubilized enzymes inactivated by heating at $100^{\circ} \mathrm{C}$. for $20 \mathrm{~min}$.

\section{Results}

Immunization of rabbits with human CMP or PP-L resulted in the production of antibodies to these proteinpolysaccharides. These antibodies were demonstrated by agar double diffusion (Fig. 1, overleaf) and tanned red blood cell agglutination tests (Table I).

TABLE I

RESULTS OF AGGLUTINATION STUDIES

\begin{tabular}{l|l|l}
\hline \multicolumn{1}{c|}{ Antiserum } & $\begin{array}{c}\text { Antigen used to Coat } \\
\text { Tanned Sheep Red } \\
\text { Blood Cell }\end{array}$ & Titre \\
\hline \multirow{2}{*}{ Anti-Human PP-L } & $\begin{array}{l}\text { Human PP-L } \\
\text { Bovine PP-L } \\
\text { Porcine PP-L }\end{array}$ & $1: 10,240$ \\
\hline \multirow{2}{*}{ Anti-Bovine PP-L } & Bovine PP-L & 2,560 \\
& Porcine PP-L & $1: 20,480$ \\
Anti-Porcine PP-L & Human PP-L & $1: 2,560$ \\
\hline & Porcine PP-L & $1: 10,240$ \\
& Bovine PP-L & $1: 1,280$ \\
\hline
\end{tabular}

Boyden tanned red blood cell agglutination study. Products were digested with testicular hyaluronidase before coating to the sheep red blood cells. Settling patterns were read after $16 \mathrm{hrs}$ at $4^{\circ} \mathrm{C}$.

All antisera were absorbed with serum from the homologous species. Antisera to human PP-L formed precipitin lines with human porcine, and bovine PP-L (Fig. 1). Agglutination studies (Table I) also indicated that PP-L from human, porcine, and bovine hyaline cartilages contain a cross-reacting antigenic determinant. Similar studies using antisera to human CMP yielded identical results. A detailed report of these immunological studies will be published elsewhere. Digestion of these proteinpolysaccharides with trypsin $(p H$ 7.4) for $48 \mathrm{hrs}$ completely abolished the reactivity of the proteinpolysaccharides with the antisera. Digestion of the proteinpolysaccharides with testicular hyaluronidase $(p \mathrm{H} \mathrm{4} \cdot 7)$ for $48 \mathrm{hrs}$ did not abolish the reactivity with the antisera.

* Lysosomes from human white blood cells were a generous gift of Gerald Weissmann, New York University, and those from rat liver were supplied by Leslie Bernstein, Albert Einstein College of Medicine. 
Fig. 1.-Agar double diffusion study of PP-L from human, bovine, and porcine cartilage with anti-human PP-L.

$$
\begin{array}{lr}
1=\text { porcine PP-L } & 5=\text { human PP-H } \\
2=\text { human PP-H } & 6=\text { human PP-L } \\
3=\text { human PP-L } & 7=\text { anti-human PP-L } \\
4=\text { bovine PP-L } & \text { absorbed with } \\
& \text { human serum. }
\end{array}
$$

Nos. 1 to 6 were digested with testicular hyaluronidase. The complete inner ring of precipitin lines (arrow) indicates that all these products contain a common antigenic determinant. The outer precipitin lines are due to a determinant specific for human PP-L and PP-H.

Fig. 2 shows that, after digestion with hyaluronidase, the immunological reactivity could be separated electrophoretically from the chondroitin sulphate fragments that had been formed from PP-L by digestion with the enzyme. The immunologically active material migrated in the same zone as the protein. These observations suggest that the anti- genic sites of the proteinpolysaccharide are in closely associated with the protein moiety of the molecule.

Normal Cartilage.-Sections of normal human $\stackrel{\mathbb{\perp}}{\circ}$ articular cartilage which had been reacted with anti- $\overrightarrow{\overrightarrow{0}}$ sera to human CMP revealed localized fluorescent 3

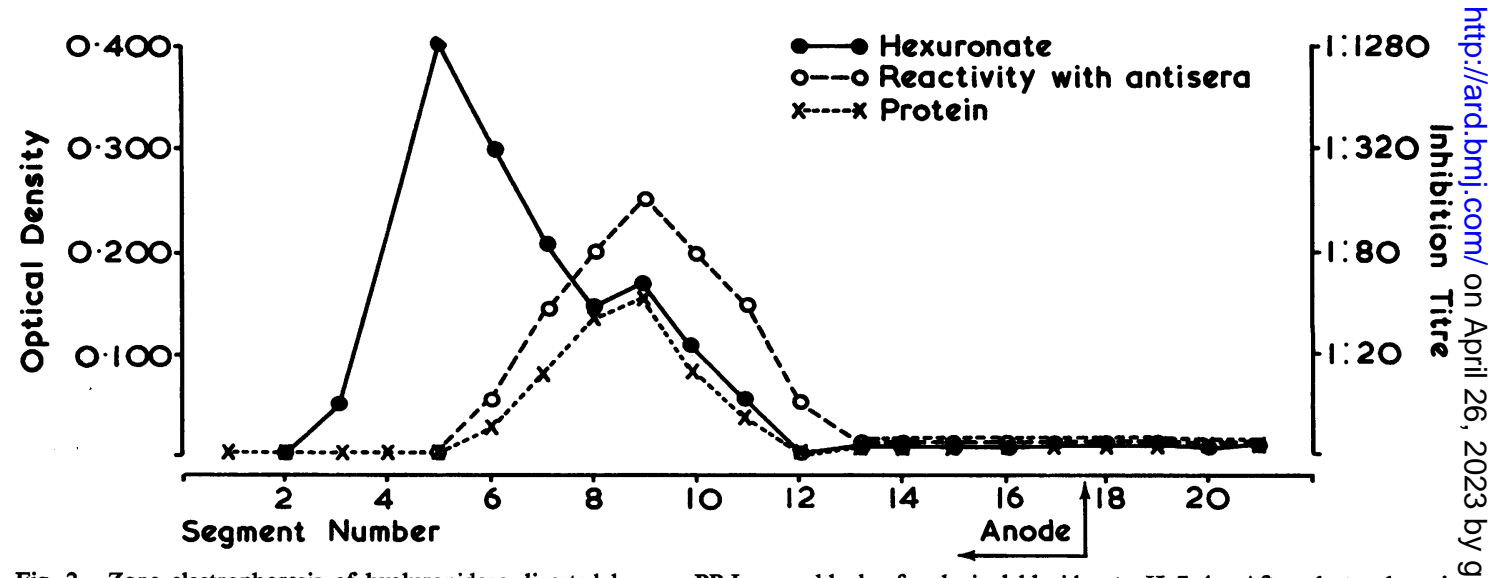

Fig. 2.-Zone electrophoresis of hyaluronidase digested human PP-L on a block of polyvinylchloride at $p H$ H.4. After electrophoresis $\subset$ block was cut into equal segments and eluate of each segment was analysed for chondroitin sulphate (as hexuronic acid), protein, and $\mathbb{D}$ ability to inhibit the agglutination of sheep cells coated with human PP-L by anti-human PP-L. Note that the serological reactivity migrated with the protein and not with the chondroitin sulphate fragments that had been formed from PP-L by digestion with hya- luronidase. 


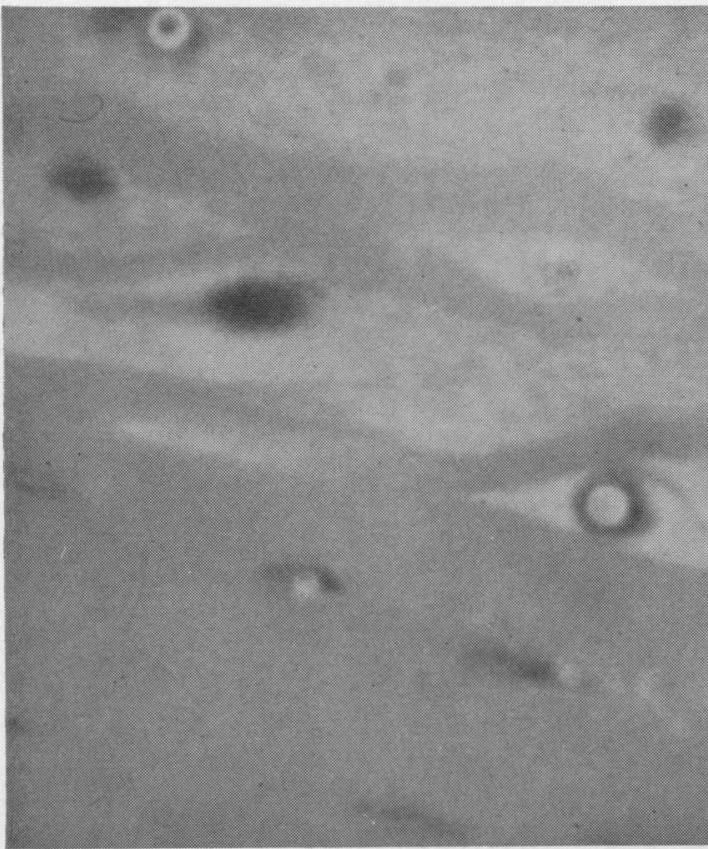

Fig. 3.- Section of junction of superficial and middle layers of normal human articular cartilage stained for CMP by an indirect immunofluorescent technique using anti-human CMP Fluorescent staining is present in the chondrocytes and lacunae, and is distributed in the matrix as narrow spindles lying parallel to the articular surface. $\times 700$

staining largely confined to the chondrocyte cytoplasm, the lacunae, and relatively small areas of peri-lacunar matrix. In the superficial zone of cartilage the peri-lacunar matrix staining assumed spindle-shaped forms (Fig. 3). In the middle and deeper zones, the matrix showed only small haloes of granular fluorescence immediately surrounding the lacunae (Fig. 4).

Sections of human articular cartilage which had been reacted with normal rabbit serum or antihuman ceruloplasmin rabbit serum showed no fluorescent staining (Fig. 5). Sections reacted with anti-human CMP absorbed with human CMP

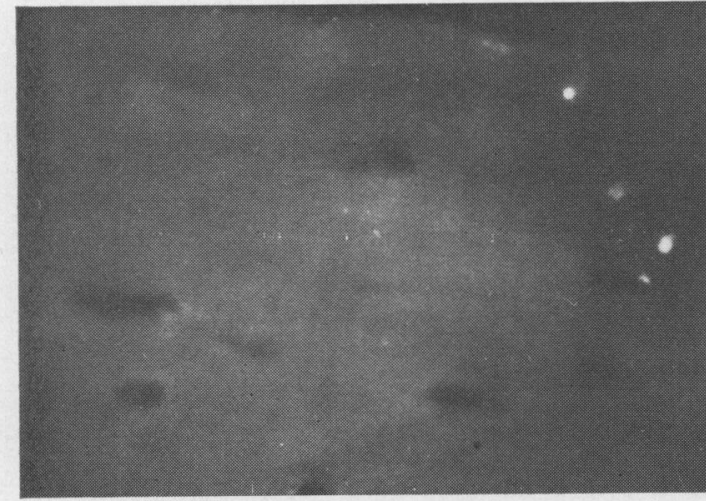

Fig. 5.-Section of deep layer of normal human articular cartilage stained with an indirect immunofluorescent technique using an antiserum specific for human ceruloplasmin instead of anti-human CMP. No fluorescent staining is noted. $\times 300$.
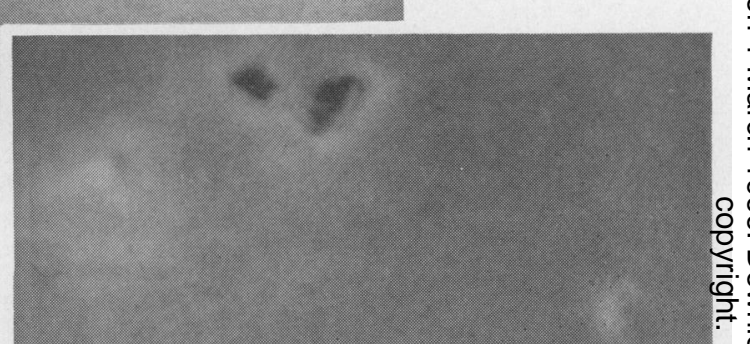

8 o 
exhibited a marked decrease in the intensity of fluorescent staining.

When human articular cartilage was reacted with the antisera to bovine and porcine CMP, the staining patterns were identical to that obtained with antisera to human CMP. These results are in agreement with the cross reactivity of human, bovine, and porcine PP-L (Table I, Fig. 1).

Osteo-arthritis.-Immunofluorescent stains for human chondromucoprotein on sections of osteoarthritic articular cartilage revealed an increased reactivity of the superficial matrix in areas where the content of anionic polysaccharides was apparently markedly diminished as judged by decreased metachromatic staining (Fig. 6). Fluorescent staining of the matrix was much more intense and diffusely distributed than that seen in the superficial zone of normal cartilage. In the deeper zones which appear normal with routine and metachromatic stains, the distribution of fluorescence was similar to that observed in the normal cartilage. In sections of early osteo-arthritic cartilage with no gross or microscopic evidence of superficial destructive changes, there was also more intense and diffuse fluorescent staining of the superficial matrix, and this was accompanied by a loss of metachromatic staining.

Enzyme Studies.-Digestion of normal human articular cartilage with testicular hyaluronidase at $p \mathrm{H} 4 \cdot 7$ produced striking changes in the distribution of immunofluorescent staining. There was increased intensity and marked widening of the fluorescent areas around the lacunae in all layers of the cartilage (Fig. 7). This staining corresponded to areas of decreased metachromasia in parallel sections similarly treated with hyaluronidase before

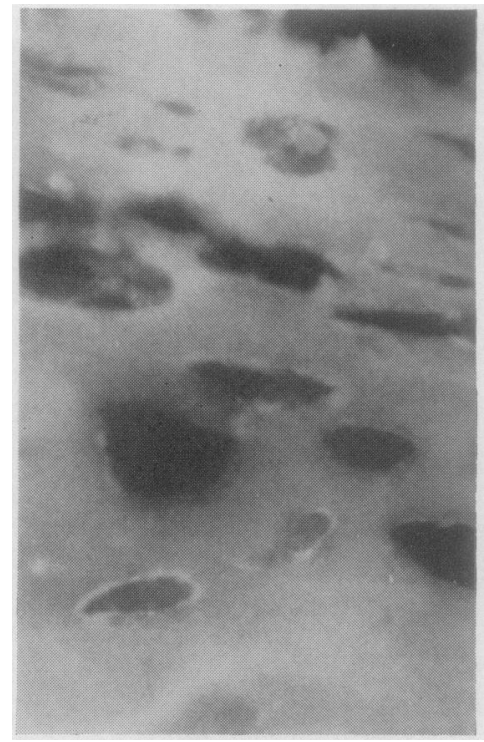

Fig. 6.-Immunofluorescent stain of superficial layer of osteo= arthritic cartilage using anti-human CMP. Staining of matrix is్ more intense and more diffuse than in superficial layer of norma cartilage. Spindle-like distribution found in normal matrix is nof seen. $\times 300$

staining with toluidine blue. In the superfical zones, these changes closely resembled the alterationso seen in osteo-arthritis. No changes were seen ins fluorescent or metachromatic staining in controp sections incubated in acetate buffer $(p \mathrm{H} 4 \cdot 7)$ withoute hyaluronidase.

Digestion of normal articular cartilage with $\overrightarrow{\overrightarrow{0}}$ papain for a short period $(10 \mathrm{~min}$.) produced equally striking changes. There was a marked loss of metachromasia from the superficial and contiguous? middle zones, with only minimal changes in the
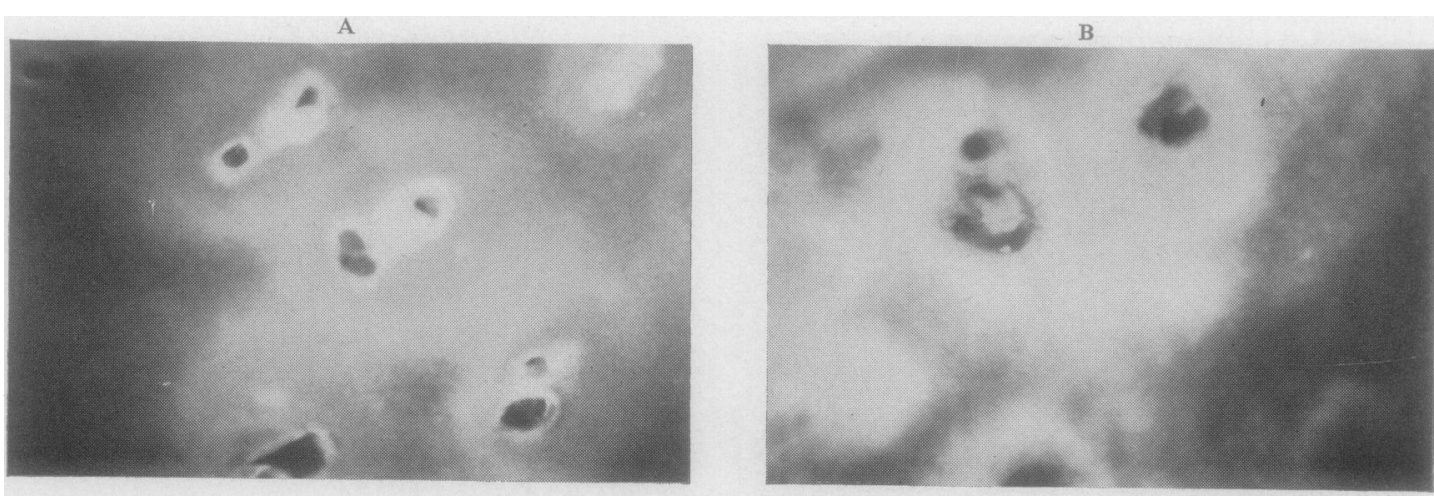

Fig. 7.- Immunofluorescent stain of deep layer of normal human cartilage with anti-human CMP after previous incubation with testicular hyaluronidase for $60 \mathrm{~min}$. (A) and $120 \mathrm{~min}$. (B). Staining of matrix more intense and diffuse than in Fig. 4 . The fluorescent haloes around the lacunae are larger and tend to coalesce $(B) . \quad \times 300$. 
deeper zones. As is the case in osteo-arthritis and after hyaluronidase, areas exhibiting loss of metachromasia revealed a marked increase in the intensity and diffuseness of the fluorescent staining in the matrix (Fig. 8). Digestion with papain for a long time (60 min.), however, resulted in a considerable loss of fluorescent staining. The metachromatic

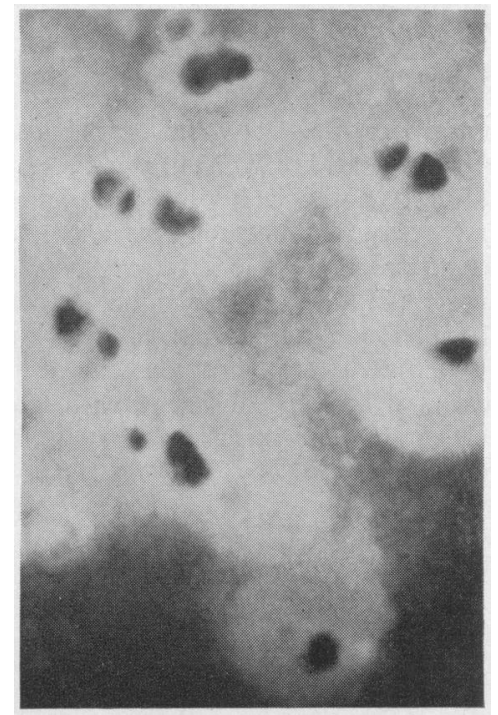

Fig. 8.-Immunofluorescent stain of deep layer of normal human cartilage with anti-human CMP after previous incubation with papain for $10 \mathrm{~min}$. Staining of matrix more intense and diffuse than in Fig. 4. As in Fig. 7 the fluorescent haloes are larger and tend to coalesce. $\times 300$.
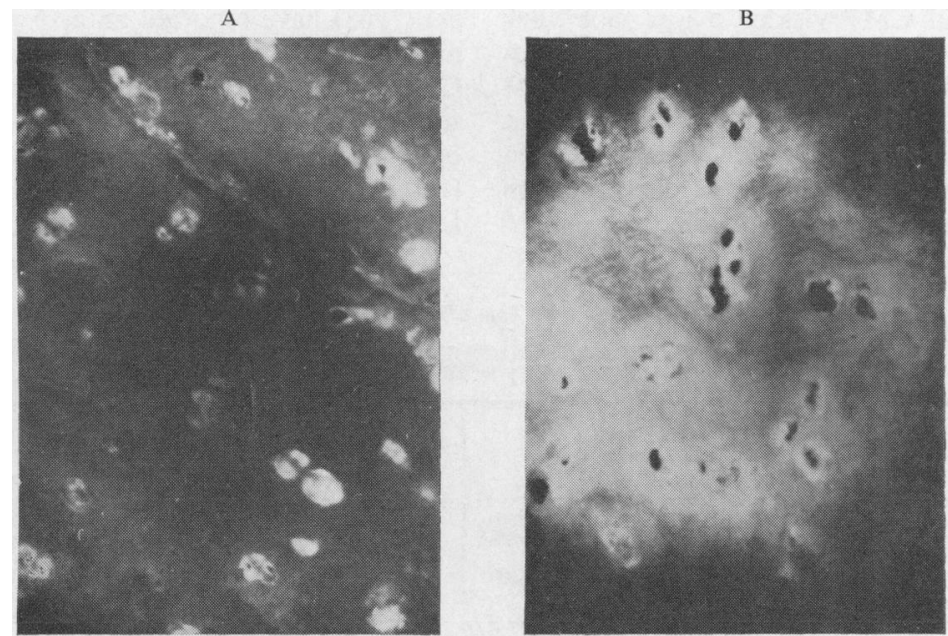

Fig. 9.-Immunofluorescent stain of deep layer of normal human cartilage with anti-human CMP after previous incubation with (A) lysosomal enzymes from rheumatoid synovial membrane inactivated by heating to $100^{\circ} \mathrm{C}$. for 20 min., (B) lysosomal enzymes from rheumatoid synovial membrane. Note marked increase in both intensity and diffuseness of fluorescent staining in B. $\times 150$.

and immunofluorescent staining of sections incubated in $0.03 \mathrm{M}$ cysteine in phosphate buffer were as in the normal undigested sections.

Digestion of normal articular cartilage with activated lysosomal enzymes produced changes very similar to those produced by hyaluronidase and brief digestion with papain. The lysosomal enzymes caused a loss of metachromasia associated with an increased fluorescent staining of the matrix in all layers of the cartilage (Fig. 9). This effect was seen after treatment with rat liver and human white blood cell lysosomal enzymes, but it was most marked after treatment with the preparation obtained from rheumatoid synovial membrane. Control sections incubated with intact lysosomes or lysosomal enzymes that had been heated to $100^{\circ} \mathrm{C}$. for 20 mins. showed no increase in fluorescence (i.e. they were identical with the undigested sections).

\section{Discussion}

The availability of antisera to CMP provides a new and specific method for studying the distribution of proteinpolysaccharides in cartilage. The metachromatic and cationic dyes used to stain chondromucoproteins react with the chondroitin sulphate and keratin sulphate portions of these proteinpolysaccharides. The immunofluorescent stains reflect reactivity with the antigenic sites which appear to be closely associated with the protein portion. When normal articular cartilage was studied with these two staining procedures, the pattern obtained with the fluorescent stain was 
strikingly different from that obtained with metachromatic stains. The fluorescent staining of the matrix was more restrictively localized than was the metachromatic staining It is unlikely that this difference is due to the existence of large amounts of free polysaccharide (chondroitin sulphate) unassociated with protein in the cartilage matrix. Studies of cartilage by Schubert (1958) indicate that nearly all the anionic polysaccharide exists as part of proteinpolysaccharide complexes. A more likely explanation of the observed differences in the staining patterns is that the antigenic sites in most of the CMP molecules of normal cartilage are inaccessible to specific antibody. Ogston and Phelps (1961) have shown that proteinpolysaccharide molecules are capable of excluding proteins from their domain. The more polymerized, the more concentrated, and hence the more entangled the CMP molecules, the more effective and nearly complete the exclusion of protein. The virtual absence of immunofluorescent staining from the inter-lacunar matrix is probably due to the increasing polymerization and entanglement of the CMP in the older matrix more distant from the chondrocytes. This hypothesis seems likely since the antigenic sites in these areas of the matrix may be made accessible by in vitro digestion of cartilage with testicular hyaluronidase or lysosomal enzymes, or by brief digestion with papain. Hyaluronidase causes this effect by removal of chondroitin sulphate and depolymerization of the CMP molecules (Meyer and Rapport, 1952). Papain and lysosomal enzymes (Dingle, 1962) also depolymerize CMP. Ziff, Gribetz, and Lospalluto (1960) found that papain digestion of CMP yielded a low molecular weight fraction containing mainly chondroitin sulphate and a fraction of higher molecular weight containing mainly protein. The loss of fluorescent staining which occurs with more prolonged digestion with papain is most likely associated with more complete proteolysis of the protein moiety.
There is a wider distribution of immunofluorescent? staining and decreased metachromasia in the superficial zone of osteo-arthritic cartilage matrix. These findings are very similar to the changes produced $\frac{}{5}$. by either hyaluronidase, lysosomal enzymes, or: papain (10-min. digestion) in normal articulars cartilage (Table II). They suggest that CMP ino osteo-arthritic cartilage is depolymerized and con-흘 tains less anionic polysaccharide than normal. Bollet, Handy, and Sturgill (1963) found an increased $\frac{\Phi}{\circ}$ ratio of protein to polysaccharide in isolated CMPO from osteo-arthritic articular cartilage. Theses authors concluded that CMP in osteo-arthritic carti- lage had been digested by hyaluronidase. Sincehyaluronidase could not be demonstrated in cartilage and since these changes in osteo-arthritic cartilage were primarily in the superficial zone, it was felt that the CMP in osteo-arthritic cartilage was depolymerized by a synovial fluid hyaluronidase.

Our data, although consistent with the above hypothesis, suggest another possible explanation foro the depolymerization of CMP in osteo-arthritic cartilage. Several investigators have demonstrated that proteolytic enzymes present in cartilage cane depolymerize CMP. Thomas, McCluskey, Potter $\stackrel{\rho}{\lessgtr}$ and Weissmann (1960) produced marked loss of metachromasia from cartilage by labilizing rabgig chondrocyte lysosomes with orally-administered vitamin A. This effect was thought to be mediato by an acid protease (i.e. cathepsin) present in lysosomes of the chondrocytes. Ali (1964) has shown that autolytic degradation of rabbit earo cartilage can occur through the action of an acide protease. Tourtellotte, Campo, and Dziewiatkow $\overrightarrow{\vec{B}}$ ski (1963) have reported an acid protease in bovine nasal septum cartilage capable of depolymerizing CMP. Our studies have shown that the altered? staining reactions in osteo-arthritic cartilage care be simulated by lysosomal enzymes and papain? (10-min. digestion) as well as by hyaluronidase 3 Liberation of lysosomal enzymes in the superficiah

TABLE II

COMPARISON OF IMMUNOFLUORESCENT AND METACHROMATIC STAINING OF SUPERFICIAL ZONE OF NORMAL AND OSTEO-ARTHRITIC ARTICULAR CARTILAGE

\begin{tabular}{|c|c|c|c|c|}
\hline & Cartilage & Normal & Osteo-arthritic & $\begin{array}{c}\text { Normal, Digested with Hyaluro- } \\
\text { nidase, Papain (10 min.), or } \\
\text { Lysosomal Enzymes }\end{array}$ \\
\hline \multirow{2}{*}{ Staining } & Immunofluorescent & $\begin{array}{l}\text { Localized to lacunae, chondro- } \\
\text { cytes, and small areas of peri- } \\
\text { lacunar matrix } \\
\text { Characteristic spindle-shaped } \\
\text { pattern }\end{array}$ & $\begin{array}{l}\text { Increased in intensity and } \\
\text { distributed throughout } \\
\text { entire matrix } \\
\text { Spindle-shaped pattern not } \\
\text { discernible }\end{array}$ & $\begin{array}{l}\text { Increased in intensity with marked } \\
\text { widening of peri-lacunar staining }\end{array}$ \\
\hline & Metachromatic & $\begin{array}{l}\text { Moderately intense throughout } \\
\text { matrix }\end{array}$ & $\underset{\text { throughout matrix }}{\text { Markedly decreased }}$ & $\begin{array}{l}\text { Loss of metachromasia in areas? } \\
\text { of matrix that showed in } \\
\text { creased fluorescence }\end{array}$ \\
\hline
\end{tabular}


layer of osteo-arthritic cartilage could produce the changes in CMP which occur in osteo-arthritis. Because of their proximity to the articular surface, lysosomes in the superficial zone of cartilage may be particularly susceptible to the unusual forces (and trauma) which frequently antedate the development of osteo-arthritis in a joint. Whether such forces could disrupt lysosomal membranes is speculative, but other types of trauma (i.e. repeated freezing and thawing) can liberate lysosomal enzymes in vitro (de Duve, 1963; Weissmann, 1964).

The possible role of lysosomes in the pathogenesis of cartilage erosion in rheumatoid arthritis has been previously discussed (Barland, Novikoff, and Hamerman, 1964). In this regard the striking effect of lysosomal enzymes isolated from rheumatoid synovial membrane on the matrix of normal articular cartilage is of considerable interest. This observation confirms that lysosomal enzymes previously shown to be present in the rheumatoid synovial membrane (Barland, Novikoff, and Hamerman, 1964) can actually alter the matrix of articular cartilage in vitro.

\section{Summary}

(1) Antisera were prepared in rabbits to the proteinpolysaccharides of human articular cartilage. With these antisera an indirect immunofluorescent technique was used to study the distribution of the proteinpolysaccharides in sections of articular cartilage.

(2) In normal articular cartilage the fluorescent staining of the matrix was restrictively localized to the peri-lacunar region of the matrix, and had a characteristic spindle-shaped pattern in the superficial zone.

(3) In the superficial zone of osteo-arthritic cartilage the fluorescent staining of the matrix was much more diffuse and intense. The areas with intense fluorescent staining showed a marked loss of metachromatic staining.

(4) The changes seen in osteo-arthritic cartilage can be simulated in vitro by incubation of normal cartilage with testicular hyaluronidase, papain (10 min.), and lysosomal enzymes.

We wish to thank Mrs. Tina Barland for her excellent technical assistance.

\section{REFERENCES}

Ali, S. Y. (1964). Biochem.J., 93, 611.

Baker, J. R. (1946). Quart.J. micr. Sci., 87, 441.

Barland, P., Novikoff, A. B., and Hamerman, D. (1964). Amer. J. Path., 44, 853.
Bollett, A. J., Handy, J. R., and Sturgill, B. C. (1963). J. clin. Invest., 42, 853.

Boyden, S. V. (1951). J.exp. Med., 93, 107.

Collins, D. H. (1949). "The Pathology of Articular and Spinal Diseases", pp. 22, 84. Arnold, London.

Dingle, J. T. (1962). Proc. roy. soc. Med., 55, 109.

Dische, Z. (1947). J. biol. Chem., 167, 189.

Duve, C. de (1963). "The Lysosome Concept", In "Ciba Foundation Symposium: Lysosomes". Ed. A. V. S. de Reuck and M. P. Cameron, p. 26. Churchill, London.

- Pressman, B. C., Gianetto, R., Wattiaux, R., and Appelmans, F. (1955). Biochem. J., 60, 604.

Gerber, B. R., Franklin, E. C., and Schubert, M. (1960). Ibid., 235, 2870.

Lowry, O. H., Rosebrough, N. J., Farr, A. L., and Randall, R. J. (1951). Ibid., 193, 265.

Malawista, I., and Schubert, M. (1958). Ibid., 230, 535.

Meyer, K., and Rapport, M. M. (1952). Advanc. Enzymol., 13, 199.

Ogston, A. G., and Phelps, C. F. (1961). Biochem. J., $78,827$.

Ouchterlony, O. (1958). Progr. Allergy, 5, 1.

Sandson, J., and Hamerman, D. (1962). J. clin. Invest., 41, 1817.

Schubert, M. (1958). Fed. Proc., 17, 1099.

Thomas, L., McCluskey, R. T., Potter, J. L., and Weissmann, G. (1960). J. exp. Med., 111, 705.

Tourtellotte, C. D., Campo, R. D., and Dziewiatkowski D. D. (1963). Fed. Proc., $22,413$.

Weissmann, G. (1964). Ibid., 23, 1038.

Ziff, M., Gribetz, H. J., and Lospalluto, J. (1960) J. clin. Invest., 39, 405.

\section{Étude immunofluorescente du cartilage articulaire humain \\ RÉSUMÉ}

(1) On a préparé un antiséreum lapin aux protéinepolysaccharides du cartilage articulaire humain. Avec cet antisérum et le procédé d'immunofluorescence indirecte on étudia la distribution des protéine-polysaccharides dans les coupes du cartilage articulaire.

(2) Dans le cartilage articulaire normal la coloration fluorescente de la matrice était localisée et limitée à la région périlacunaire de la matrice et dans la zone superficielle elle présentait une image fusiforme caractéristique.

(3) Dans la zone superficielle du cartilage ostéoarthritique la coloration fluorescente de la matrice était beaucoup plus diffuse et intense. Les régions à la coloration fluorescente intense accusaient une perte prononcée de coloration métachromatique.

(4) Les altérations observées dans le cartilage ostéoarthritique peuvent être simulées in vitro par l'incubation du cartilage normal avec l'hyaluronidase testiculaire, papaïne (10 minutes), et des enzymes lysosomiques.

\section{Estudio inmunofluorescente del cartílago articular} humano

SUMARIO

(1) Se prepararon antisueros en el conejo contra los proteina-polisacaridos del cartílago articular humano. 
Con estos antisueros y el método de inmunofluorescencia indirecta se estudió la distribución de los proteinapolisacaridos en los cortes del cartílago articular.

(2) En el cartílago articular normal la coloración fluorescente de la matriz fué localizada y limitada a la región perilacunar de la matriz y en la zona superficial presentó un cuadro fusiforme característico.

(3) En la zona superficial del cartílago osteoartrítico la coloración fluorescente de la matriz fué mucho más difusą e intensa. Las regiones con coloración fluorescented intensa acusaron un desperdicio pronunciado de las coloración metacromática.

(4) Las alteraciones observadas en el cartílago osteo artrítico se pueden simular in vitro por la incubación? del cartílago normal con hialuronidasa testicular, papaina (10 minutos) y encimas lisosómicas. 